\title{
The Surreal Creativity in Windows Display Design
}

\author{
Huda Othman \\ Associate Dean, School of Architecture and Design, American International University, Kuwait.
}

\begin{tabular}{l|l|l|} 
Submit Date: 2021-04-02 08:43:21 & Revise Date:2021-07-08 18:14:53 |Accept Date:2021-08-06 09:14:14
\end{tabular}

DOI:10.21608/jdsaa.2021.70638.1103

\section{KEYWORDS:}

Surrealism Art, Windows Display, Modern Art, Contemporary Design, Surrealist-Themed Designs

\begin{abstract}
:
This paper is a close-up study of the influences of Surrealism as an art movement on the design practices of window display. The main objective of this paper is to describe and analyze the effects of surrealism approach on windows display design as a creative design strategy, and to analyze its characteristics such as creativity and originality. The importance of this paper is to explore what is the Surrealist approach in windows display designs, and to explore the key influences and motives that were the foundation for Surrealist thought in display. The research questions were set out are: What is the Surrealist approach in windows display designs and its characteristics? What is the role of Surrealism in contemporary windows display design? What are the techniques of Surrealist-themed windows display? How did Salvador Dali use the aesthetics, characteristics, and techniques of Surrealism in his windows display design? How do the famous brands "Tiffany \& CO, Hermès, and Selfridges" use the Surrealism approach as a creative design strategy for their windows display designs? This paper assumes that the Surrealist Themed windows display designs feature the elements of surprise, unexpected juxtapositions and non sequitur, which strongly catch the attraction of customers to the store. It also assumes that the using Surrealism in windows display design as a creative approach helps the customers to prefer the product or service being marketed. This paper follows the descriptive method to describe the Surrealism approach as a creative design strategy of windows display design throughout the study of the aesthetics, characteristics, and techniques of Surrealism in display design. This paper also uses the analytical method to analyze Salvador Dali windows display designs, also to analyze a chosen example of windows display for the famous brands "Tiffany \& CO, Hermès, and Selfridges" that use Surrealism in their windows display designs.
\end{abstract}

\section{Introduction}

Surrealism is an art and design trend that creates jarring, fantastical illustrations and paintings dedicated to unleashing the expressions of the unconscious mind. As a result, it's not just about art: it's about reconciling the artist's dreams with tangible reality to create a so-called absolute reality. As a design movement, it has left behind evocative imagery that comes straight out of adherents' dreams and nightmares. (Martin, 2018, design trends report. Avail- able at: https://webdesigntips.blog/web-design/photoshop-tips-tricks/design-trend-report-surrealism, Accessed 07.07.2020) The Surrealism art movement had a great impact in art, design, literature, culture and even extending to politics. Surrealism is a creative act of effort towards liberating the imagination, it is as dynamic as it is subtle; Surrealism is still alive and growing until today, as Many artists around the world are influenced by Surrealism styles, ideas \& techniques. (https://1stwebdesigner.com/modern- 
surrealism/. Accessed 08.07.2021). Surrealism taught the world to see art not merely visually and literally; but to appreciate it in a subconscious level as well. Surrealism took its place in the human lexicon and quickly grew to be an influential force on human thought and expression.

(https://www.britannica.com/art/Surrealism, Accessed 08.07.2021). Surrealists, the movement began to cross-over into the commercial, material world. Escaping the bounds of a radical avant-garde art movement, the leading Surrealist artists often worked as commercial designers themselves, particularly in the fields of advertising, graphics, theatre, film, and shop window designs. Wood, 2007, https://www.vam.ac.uk/articles/surrealism-anddesign, Accessed 08.07.2021). Today, surrealism is a familiar form of art that continues to grow globally. Surreal art can be dreamy or gritty; or it can be optimistic or depressing. (https://1stwebdesigner.com/modern-surrealism/.

Accessed 08.07.2021). Windows display designers understand now that there's a lot to be done in order to capture as many customers as possible. Creativity and originality are still very good ways to ensure visibility for the brands and products in windows display designs, because we live in a world that demonstrates a serious desire for reevaluating the possibilities of artistic expression that existed in the past, so windows display designers direct their attention towards a more artistic approach of the phenomenon of windows display design. Designers' endeavor can be seen as a form of art, if they maintain this desire of being original and creative, so many of windows display designers around the world are influenced by Surrealism styles, ideas and techniques. It's easy for display designers to show their creativity through Surrealism, because the style provides them more freedom to convey their feelings and thoughts through the display design. Windows display can tell a story, to represent the brand's values and inspire the customers. It highly contributes to the first impression that customers get from the brands. The single and most important value of windows display is to engage and inspire the customers, encourage them to buy the products that the retailers want them to buy and therefore increase the sales, margin and return on space. If shoppers can feel a certain message delivered to windows display practices within a store, they will feel motivated to get involved with the brand. Nowadays many of the leading display brands drew inspiration from the modern art, where new ideas regarding branding, marketing and consumer behavior evolved. As the modern ideas on marketing spread there was simultaneously a paradigm shift in display aesthetics. Consequently, window display designers combined ideas from modern art approaches with the ideas and aesthetics of functionalism. One significant factor for this development was most certainly the semi-open boundaries between art and commercial and everyday visual culture. This paper is a close-up study of the influences of Surrealism as an art movement on the design practices of window display.

\section{Objectives of The Paper}

The main objectives of this paper are:

- To describe the effects of surrealism approach on windows display design as a creative design strategy.

- To explain the elements of the Surrealist Themed window display

- To analyze the characteristics of Surrealism design approach such as creativity and originality

\section{The Paper Significance}

The importance of this paper is to explore what is the Surrealist approach in windows display designs, particularly the display designs of Salvador Dali. Also, to explores the key influences and motives that were the foundation for Surrealist thought in windows display.

\section{The Problem of the Paper}

To achieve the objectives of this paper, several research questions were set out as the following: 
1- What is the Surrealist approach in windows display designs and its characteristics?

2- What is the role of Surrealism in contemporary windows display design?

3- What are the techniques of Surrealist-themed windows display?

4- How did Salvador Dali use the aesthetics, characteristics, and techniques of Surrealism in his windows display design?

5- How do the famous brands "Tiffany \& $\mathrm{CO}$, Hermès, and Selfridges" use the Surrealism approach as a creative design strategy for their windows display designs?

\section{The Hypotheses of the Paper}

- The using of Surrealism in windows display design strongly attract the passersby attention to the store and encourage them to take the purchase decision.

- Surrealist Themed windows display designs feature the elements of surprise, unexpected juxtapositions and non sequitur, which strongly catch the attraction of customers to the store.

- Use Surrealism in windows display design as a creative approach helps the customers to prefer the product or service being marketed.

\section{The Methodology of the Paper}

This paper follows the descriptive method to describe the Surrealism approach as a creative design strategy of windows display design throughout the study of the aesthetics, characteristics, and techniques of Surrealism in display design. This paper also uses the analytical method to analyze the display designs of the well-known surrealist artist Salvador Dali for both "Bonwit Teller Store" and "Les Chants de Maldoror". The paper also analyses some contemporary window display designs for three famous brands that frequently use and highlight the Surrealism approach in their display designs, they are Tiffany \& CO, Hermès, and Selfridges that use the Surrealism as a creative design theme for their display.

\section{Theoretical Framework:}

The window display is the primary medium through which stores first reach out to the public. It is a stylistic statement that can be read by consumers for evidence of the quality and personality of the business that it advertised. Windows display is presenting the products to customers in the most attractive way with a focus on driving commercial performance and maximize sales. The impact of visual appeal cannot be overstated in retail. (Orr, 2017). There is a theory that states a curious fact and it demonstrates the flexibility of the market: supply creates its own demand (Say's Law). It is a fact that has a major impact on the way in which retailers should create their marketing strategies. Now, the main emphasis is based on the way in which retailers attract customers, rather than just based on satisfying their needs. In other words, windows display is seen as a phenomenon that not only makes products more visible for customers, but it also has an impact on the way in which people evaluate their need for different types of goods. (https://mannequinmall.com/blogs/posts/attractingattention-with-surreal-window-display-design. Accessed 26.06.2020). The successful windows display, functioning in its capacity as a selling force accomplishes the following results: First, it attracts the attention of the passerby to the merchandise on display in the store window; second, it arouses an interest in the merchandise; third, it creates the desire to possess; and, fourth, the will to have. Every display, perfect in construction and arrangement, has this power over the open mind of the shopping public, and such an instrumentality for sales, may be properly considered the most formidable equipped salesman of the stores selling force. (Orr, 2017). Retailers have exhibited their goods ever since they started to sell them, but they first utilized an artistic expression of storefronts. The density of stalls and stores in cities grew, and modest signboards were turned into complex, decorative metalwork signs, whose artistic level represented prestige of craftsmen and attracted customers. The invention of plate glass in the beginning of the 19th century along with new possibilities of creating wide windows brought artistry to another level. The size of display windows and their transparency allowed retailers to present their decorative installations to clients. (https://thecityateyelevel.com/stories/art-in-displaywindows-as-a-street-catalyst/- Accessed 19.12.2020) The window display can talk to the general public in a much stronger way than the most excellent drawing or photograph, because it shows the commodity itself. The window display is the most honest advertising medium, literally being real objects put behind transparent glass. The size, color and shape of the 
product would be presented exactly as they were. According to (Dahlgren, 2010) no transformations of appearance by retouch, cropping or choice of angle were possible. The fashionable light colors and absence of distracting decoration are of course part of the same ideal that would add to the rationality of the display. Contemporary professionals commonly described the window display as an image and pointed out the affinities between displays and printed advertisements. They recommended the shop owner to coordinate the marketing, thus the window displays, and printed ads should have the same layout and style. An efficient window display should have a poster character and catch the attention of passers-by in the same way as a well- designed poster. (Dahlgren, 2010). According to (Kiesler, 1930) the department store was the true introducer of modernism to the public at large. It revealed contemporary art to American commerce. (Dahlgren, 2010) states the majority of earlier studies on window displays have been undertaken by cultural and social historians. Even though the look of the windows is in some cases discussed by these writers, their focus is on the function of the shop window as a commercial message that reveals prevailing cultural concepts of shopping, selling and consuming. The shop window as an aesthetic phenomenon and its relation to art, however, is not very pronounced. (Walden, 1989). (Klonk, 2005) is an exception, having written on the formal similarities between displays of art and displays of goods in early twentieth-century Germany. She points out that the change in display design that occurred simultaneously in the art galleries and street windows was not only a change in appearance but also implied different ideas concerning perception. Art displays and window displays changed, from appealing to sensual and emotional sophistication, to give arguments to the rational mind. (Klonk, 2005) argues that the rational display strategies in art and commerce were shortlived and not used on a large scale. On the contrary, functionalistic ideas permeated the display trade, and led to significant changes in marketing strategies in general as well as display practices and aesthetics. (Dahlgren, 2010). The window display design represents the entire joint of visual merchandising aspects that make an entity visible. The connection of this definition with the notion of windows display is not purely random: it uses the principles that exist in the whole process of creating meaning in order to develop a more complex relation between the individual and a world filled with means to satisfy the needs and desires. The modernist windows display design would enhance decipherability and memory and thereby influence consumer behavior. The display window is a multi- medium oscillating between being an image and a three-dimensional space, and it can literally and metaphorically be a stage where theories of modern psychology, marketing, modernist aesthetics and cultural patterns of distribution, selling and consumption converge. The window display is essentially a multi- faceted medium. In writings on marketing, it was described as a two-dimensional image but also as a three-dimensional space. https://visualretailing.com/blog/2018/2/the-powerof-storytelling-in-visual-merchandising (Accessed $\underline{19.12 .2020)}$

\section{The Role of Modern Art in Windows Display:}

Back in 1929, during the Great Depression in the US, New York City retailers needed a new way to lure shoppers into their stores. Bonwitt Teller, a department store from Fifth Avenue, found a way to accomplish that. A surrealist, Salvador Dali was engaged in designing their display windows. Although his first art piece for Bonwitt Teller was not highly regarded by New York's shoppers, it certainly drew the attention to the department store. The time of truly artistic display windows begun and over the next decades Bonwitt Teller hired more artists, including Jasper Johns and Robert Rauschenberg in 1955, and James Rosenquist in 1959, who was also working for other retailers at that time - Bloomingdale's and Tiffany. In 1961 Bonwitt Teller was advertised with Andy Warhol's paintings in the display windows. Until now, the display windows are designed most often by artists, or artistic souls, but it is not the retailer's intention to dress the shop windows only to attract shoppers. Nowadays, during the era of the internet and the popularity of shopping malls, the role of the storefronts is not only to attract consumers. They need to provide a decent shopping experience and improve the public space. A recently coined term "window shopping", which describes the activity of strolling along the storefronts and admiring goods, as well as the popularity of high retail streets confirm that we are attracted by nicely designed storefronts. (https://thecityatevelevel.com/stories/art-in-displavwindows-as-a-street-catalyst/ - Accessed 19.12.2020) 
The early twentieth century was characterized by transgressed boundaries between art and everyday culture. In the histories of art, the influx from popular culture to art movements like cubism, Dadaism, Surrealism, Futurism, and Pop art is well described, as are the efforts to move art into everyday culture. The constructivists argued for purposeful art for the masses, preferably graphic designs, book illustrations, fashion and exhibition design but also, and less known, designs for purely commercial purposes like advertising posters, packaging, and windows display. As Andy Warhol once said: "Someday, all department stores will become museums and all museums will become department stores." The work of visual design of the last century is influenced by the artistic styles that have defined certain aesthetic, conceptual or ideological characteristics shared and assimilated in certain eras. Windows display designers have obviously to stay up to date on latest art and design trends yet understand the values and history of the brand they are representing through their merchandising strategies. On the world's most exclusive streets, shop fronts represent the place where fashion and fantasy collide. In the hands of a talented window display designers, they are portals into the inner sanctum of a brand and a microcosm of how it perceives itself. Mediating between a designer's vision and commercial demands, the skill of the window dresser resides in the transformation of stock into works of art or "street theatre" that have the power to captivate an ever more discerning set of pedestrians. (https://www.ft.com/content/33b297a8-4cdd-11e5b558-8a9722977189 - (Accessed 19.12.2020) Great window display design should produce seamlessly clear storytelling through aesthetic sensibility and creativity. Merchandisers themselves must be connoisseurs of lighting, layouts, window dressing, and advertising graphics. Merchandisers must become master storytellers creating a world that customers can step into. They must choose the right decor, products, and branding to design and curate the perfect exhibition showcase concept expertly telling stories with merchandise that connects with the needs, desires, and the imagination of customers. Surrealism is the cornerstone of creative advertising, but the same is true for windows display. Today's consumers no longer simply want to buy, they're looking for a rewarding shopping experience. Surrealism is a great creative way of conveying what the brand is about. It helps create a value proposition, a point of difference, and connecting products to a brand's mission. Additionally, good use of surrealism characteristics is worth remembering and sharing a must in our current social landscape. The most important part is to present the merchandise in visually and imaginative ways that it engages the customer and compels them to buy. https://visualretailing.com/blog/2018/2/the-powerof-storvtelling-in-visual-merchandising (Accessed $\underline{19.12 .2020)}$

\section{Surrealism Approach in Windows Display:}

The relationship between brands and the shop windows display began with the invention of single sheet, plate-glass windows in the 1840s. It was these supersized windows that allowed shop fronts to be elevated into epic stage-sets. I've chosen here to talk about the possibilities of artistic expression offered by surrealism in windows display design, a very popular cultural movement. The choice has much to do with the multiple elements that the surreal movement used throughout time in order to produce its art. From a vast sphere there's lot to choose. Let us understand first the principles on which surrealism is based on. Firstly, what captures the attention when looking at a surreal picture for example is the visible intention to "resolve the contradictory conditions of dream and reality." The scenes seem illogical, very realistic, technically speaking (with a touch of hyperrealism even), a combination between strange everyday objects and a totally different approaches of beings. Surrealism is based on the idea of surprise; unexpected juxtapositions and it was seen at that time as a revolutionary movement. The surreal movement has been exploited also by store designers. It is wellknown the fact that Dali, Rene Margarette and Juan Miro, a surreal French artist, created windows display designs. The use of surreal designs is not the only choice that store designers have in order to create surreal displays. There are a lot of themes and motifs to be developed in a personal way, based on the surreal imagery, like dream, vision, or flow. (https://mannequinmall.com/blogs/posts/attractingattention-with-surreal-window-display-design. Accessed 26.06.2020). Using these themes, it can generate a lot of ideas and it can make them come to life by using the so-called "surreal objects" as props, like clocks, birds, flowing / melting objects (or create the impression of flowing), objects that fuse with 
others. The result is catchy and surprising, just as the surreal art was seen, and this is the reason why it is very used in different fields of activity, others than art. The point of turning window displays, art installations and shopping areas over to the surreal was to provide people with "retail theatre", or a shopping experience unlike anywhere else. (Lee, 2003) states that the surrealism for the revelation of the unconscious realms shares the inner world of mentality with modern fashion display for the visual expression of sensation each other.

\section{Surrealism in Contemporary Windows \\ Display Design:}

Surrealism thinks of how dreams operate: you'll be in a place from your past, then suddenly, a person or thing appears that totally doesn't fit the situation. "When common but unrelated things in surprising juxtapositions create something otherworldly and powerful, that's surrealism". (Hooks, 2018) Surrealism continues to weave itself within modern life and communication, exploding signification relationships and challenging how we communicate and live. Surrealism often takes the form of hypercreativity and features the element of surprise using random objects and unpredictable juxtapositions. "When Andre Breton first released the 'Manifesto of Surrealism' in 1924, he intended for it to influence the mass public and inform them of the tacit purpose that each Surrealist artist' work would be created from. The manifesto defines Surrealism as "Psychic automatism in its pure state, by which one proposes to express verbally, by means of the written word, or in any other manner the actual functioning of thought. The fact was that Surrealist themes lent themselves to commercialization it "precipitated its own commodification through both its thematic preoccupations and formal developments." (Daly, 2013). Dictated by the thought, in the absence of any control exercised by reason, exempt from any aesthetic or moral concern". (Breton, 1969). Breton believed in using surrealism in every aspect of creative life. Surrealism rejects the rational ideas and instead finds great value in the unconventional, the outmoded and the unconscious. Mirroring the thematic exploration of wonderment, surrealists were drawn to the fascination and beauty that poets and artists found in the unexpected. As windows display designers want to create eye-catching, memorable images it is important to use something novel something new and unusual, as it is more likely to be recalled than something expected or redundant. A Surrealist idiom remains pervasive in contemporary graphics and advertising. "The dreamlike images of the Surrealist movement play perfectly into the wishes of the display designer who want to catch the "customers' attention, to fuel their fantasies and to induce them into view a product in a new light". (Daly, 2013). Surrealism, the other primary creative trend of 20th century high culture, has been even more influential. Desire, surprise, dream, disruption, unconscious attachment, fetishism these Surrealist themes have all now been coopted to the world of brand. Shorn of the critical purchase they once had as a result of Surrealism's synthesis of Karl Marx and Sigmund Freud, these terms now operate freely and unselfconsciously as competence in consumerism. (https://www.designweek.co.uk/issues/8-march2007/rare-commodities/ - (Accessed 12.07.2020)

\section{The Techniques of Surrealist-Themed}

\section{Windows Display:}

The analysis of the influence which surrealist technique exerts on windows display design is shown as follows:

- The surrealist technique elevated the dramatic effect of the sales room by scraping the perspective, or the principle of visual arts.

- It maximized the effect of subject of the display by coinciding surrealism with realism. (Lee, 2003)

- The surrealist technique which distorts the things heralded the strong message to customers by letting them keep away from the fixed idea.

- Humorous expression of display brought about the effect of sales stimulation by giving astonishment, shock and exaggeration. 2013)

- Expression of surrealism and realism caused customers to feel shock, illusion, fantasy.

- Display hinted from nature satisfied the mental desire of the human beings to be assimilated with nature. (Lee, 2003)

- The formative characteristic presented the new possibility of combination of display with arts through the surrealism sensation.

\section{Salvador Dali's Window Display Design}

Spanish artist and Surrealist icon. Salvador Dalí is perhaps best known for his painting of melting clocks, The Persistence of Memory. His work employed a meticulous classical technique, influenced by 
Renaissance artists, that contradicted the "unreal dream" space that he created with strange hallucinatory characters. "Salvador Dalí: His dreamlike aesthetic and magnetic public persona gave rise to the most recognizable and memorable imagery that came from the period. His awareness of the publics' perception of him aided him in manipulating his work into 'spectacle'. In collaboration with fashion designer Elsa Schiaparelli, he re-appropriated the 'marvelous', making 'the fantastic real' using the body as the primary agent in commodifying the Surrealist style". (Daly, 2013). The most visible surreal artist is Salvador Dali, now seen as a very interesting character, depicted in lots of ways. His works and lifestyle have inspired a lot of people, from musicians to designers. Basically, almost everything that is surreal can be seen in his works. The famous surrealist artist Salvador Dalí participated in several commercial projects in the U.S including window display. Surrealism was greeted with enthusiasm for its applications to advertising and display designs. At the Advertising and Marketing Forum in New York in January 1937, the art director of Condé Nast publications declared that Surrealism "deals primarily in the basic appeals so dear to the advertiser's heart."

\section{1- Dali's Window Display for Bonwit Teller Store:}

The most prominent commercial application of Surrealism outside the museum was a set of windows that debuted at the fashionable Bonwit Teller department store on Fifth Avenue. From 1929 to 1980, Bonwit Teller was one of those dazzling wintertime stops, a high style ladies' retailer on Fifth Avenue. But, Bonwit Teller's window displays were much more than glitter and women's wear. In 1929, the store hired their first artist as window display designer: the eccentric Salvador Dalí. And a fascinating history of creative collaborations was born. Surrealist Salvador Dali, who once declared "I myself am surrealism" designed two themed windows for the store in 1939 one representing Day and the other Night.

\section{(https://www.theartstory.org/blog/category/public- art/\#post-707 - (Accessed 19.12.2020)}

"Zalman, 2018 details that "Bonwit Teller took out a newspaper advertisement on the Sunday before Christmas 1936 “Figure 1", not to showcase alluring models or its latest merchandise, but instead urging shoppers to come to the store to see the new window displays, one of which was designed by Surrealist artist Salvador Dalí. The ad illustrating a disembodied eye proclaimed Bonwit's inspiration to be the "sensational shows of Surrealist paintings at the Museum of Modern Art and the Julien Levy Gallery," cleverly gesturing to other trendy institutions of display. An article appearing the same day as the ad noted: "To distract thousands of women bent on Christmas shopping, on the last Saturday before Christmas is not easy. But these eight Bonwit Teller windows stop traffic and evoke hundreds of comments of admiration, amusement or revolt. Never indifference, however." Even in this diluted format, Surrealism's eye-catching quality proved effective." (Zalman, 2018)
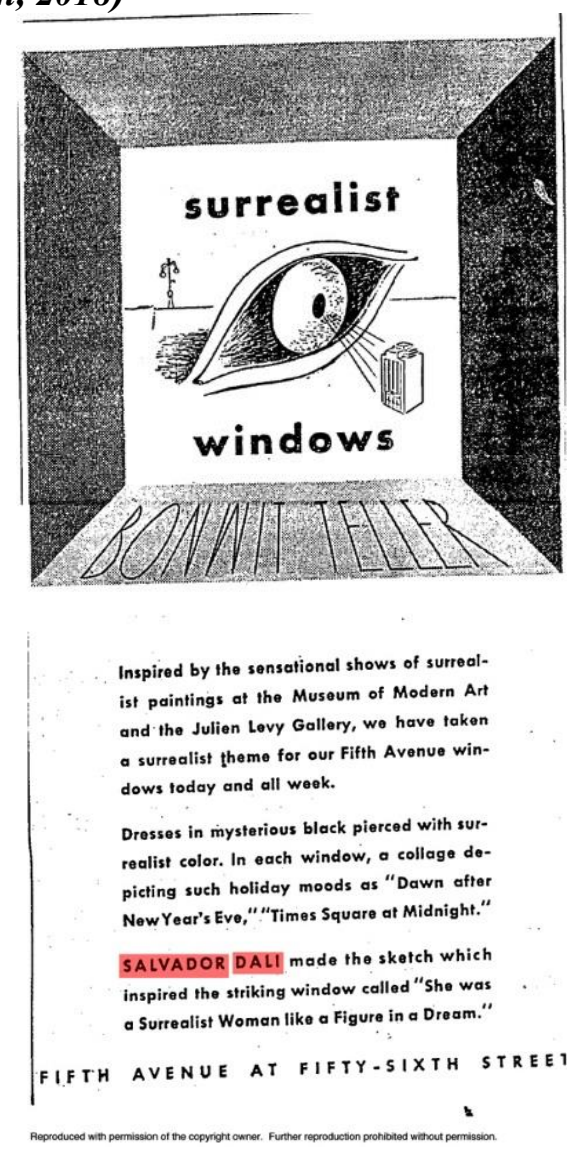

Figure: 1, Bonwit Teller advertisement in the New York Herald-Tribune. December 20, 1936.

https://www.drivingfordeco.com/stewart-and-company/ (Accessed 07.07.2020)

In The Secret Life of Salvador Dalí, the artist recalls the commission to create this window display for the famous department store on New York's Fifth Avenue: 'By way of demonstration, I accepted an offer to dress one of the windows of Bonwit-Teller's shop with a surrealist display. I used a manikin whose head was made of red roses and who had fingernails of 
ermine fur. On a table, a telephone transformed into a lobster; hanging on a chair, my famous "aphrodisiac coat".' In the window display, both the female mannequin and the table can be related to the iconography of the 1935 painting Woman with Head of Roses, while the telephone and the jacket are identified as sculptural works. The floor was covered with spoons and various objects and fashion accessories hung from the elongated arms projecting through the side walls. This window display is a good example of Dalí's involvement with the world of fashion during the 1930s. "Figure 2 ". (https://www.salvador-

dali.org/en/artwork/catalogue-raisonnesculpture/obra/7deab9bd42ece411947100155d647f0 b/she-was-a-surrealist-woman-she-was-like-afigure-in-a-dream, Accessed 26.06.2020)

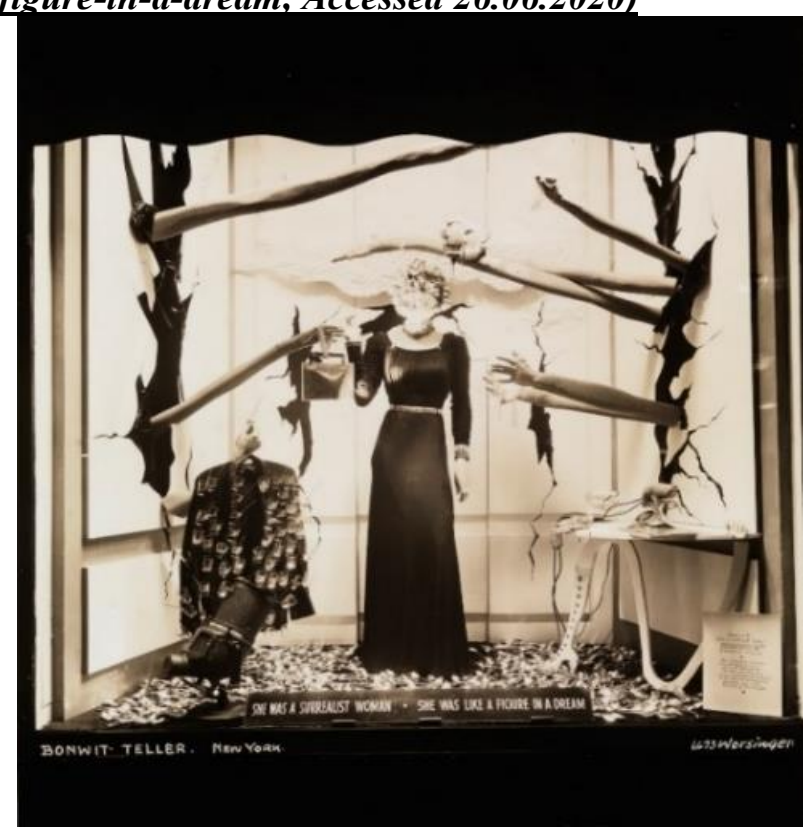

Figure: 2, Based on a sketch by Salvador Dalí. Photo Credit: The Museum of the City of New York / Art Resource, NY. Source: Museum of the City of New York -

https://scalar.usc.edu/works/the-space-between-literature-andculture-1914-1945/media/fig-2--based-on-a-sketch-by-salvadordal--photo-credit--the-museum-of-the-city-of-new-yo - (Accessed $\underline{07.07 .2020)}$

Dalí's designs has been affected by his fine art paintings (especially Three Surrealist Women "Figure 3" and Lobster Telephone “Figure 4", both 1936). Dalí was highly productive, expanding his practice beyond the visual arts into a wide array of other creative interests. He designed jewelry, clothing, furniture, sets for plays and ballets, and display windows for famous retail stores. Dalís eccentric personality often took center stage in many of these

pursuits, for example, while being consigned by the department store Bonwit Teller, Dalí was so angered by changes to his artistic vision.

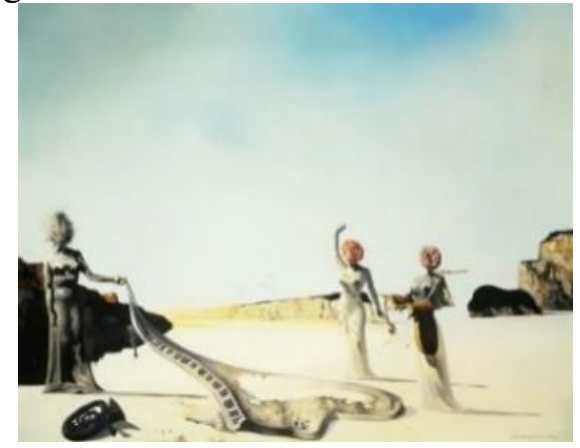

Figure: 3, Three Young Surrealist Women https://www.salvador-dali.org/en/artwork/catalogue-raisonnepaintings/obra/418/three-young-surrealist-women-holding-intheir-arms-the-skins-of-an-orchestra - (Accessed 07.07.2020)

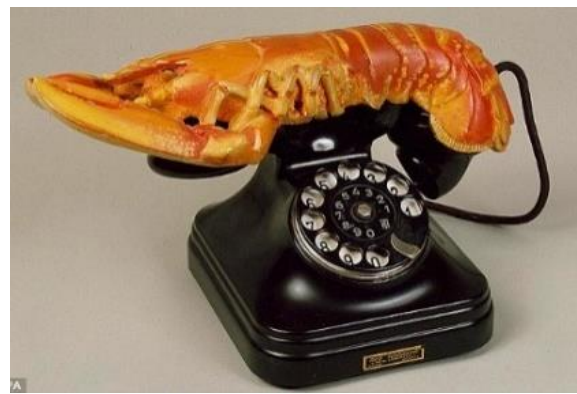

Figure: 4, The Lobster Telephone

https://expressdigest.com/salvador-dalis-lobster-telephone-willleave-uk-unless-buyer-found/ - (Accessed 07.07.2020)

In 1936, Bonwit Teller invited a number of artists to design its window displays. "Figure 5"

In a comparison to Salvador Dali's surrealist-themed display for Bonwit Teller "Figure 2", the displays shown below were much conventional design.

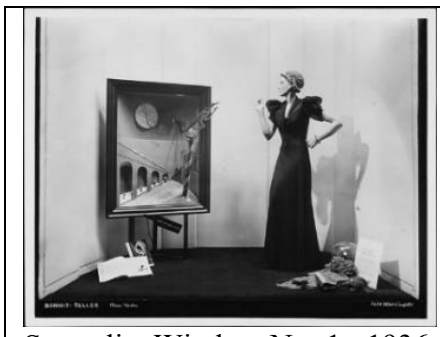

Surrealist Window No. 1., 1936. Worsinger Photo, Museum of the City of New York

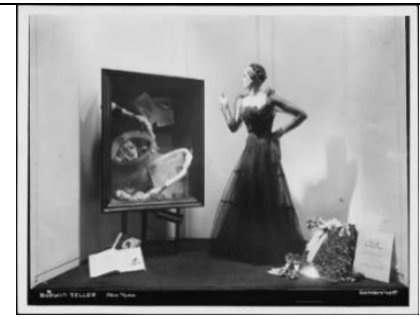

Surrealist Window No. 2., 1936 Worsinger Photo, Museum of the City of New York. 


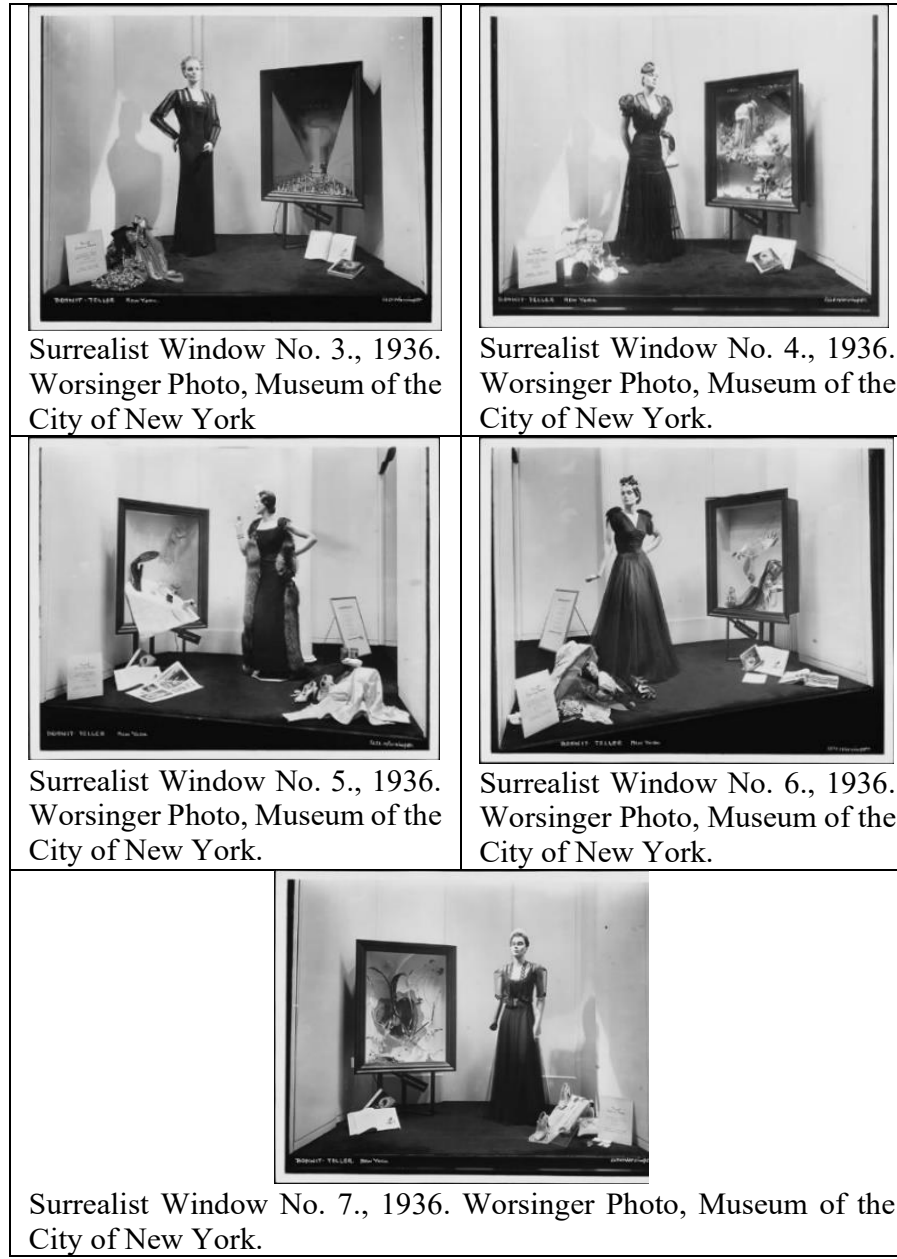

Figure: 5, the other seven windows were inspired by Dalí's work. Photo Credit: The Museum of the City of New York / Art Resource, NY. Source: Museum of the City of New Yorkhttps://scalar.usc.edu/works/the-space-between-literature-andculture-1914-1945/media/fig-2--based-on-a-sketch-by-salvadordal--photo-credit--the-museum-of-the-city-of-new-yo - (Accessed $\underline{07.07 .2020)}$

2- Dali's Window display for the exhibition «Salvador Dali 42 etchings and 30 drawings for Les Chants de Maldoror":

This work is part of the window display for the "Librairie Les Quatre Chemins" bookshop in Paris "Figure 6", on the occasion of the exhibition dedicated to the Skira edition of Les Chants de Maldoror. As Dalí himself noted: 'The legs of the chair were submerged, one in a shoe, another in a glass containing milk, another in another glass containing urine, and another in another glass containing blood. In the center of the chair there is a raw steak'. In addition, there is a shoe affixed vertically to the back of the chair, in the middle of inkwells with quills, elements that are part of Dalí's iconography and of some of the most important Surrealist objects of this period. Although it has not been possible to establish a direct link, it is very likely that this work is closely related to Chaise atmosphérique, a Surrealist object presented by Dalí in 1933 at the Galerie Pierre Colle n Paris.

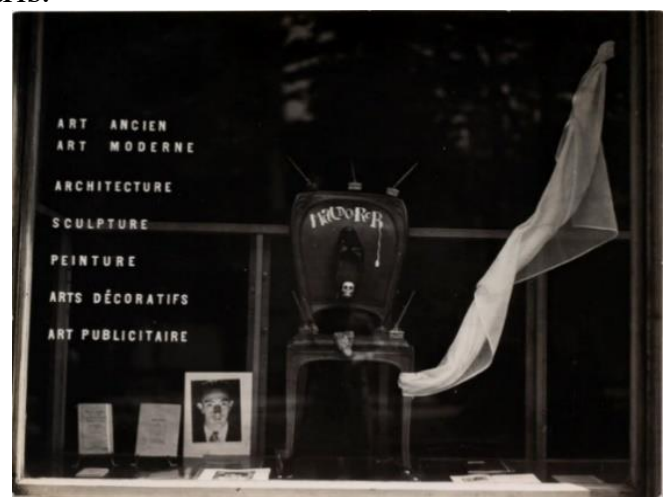

Figure: 6, Window display for the exhibition «Salvador Dali 42 eaux-fortes et 30 dessins pour Les Chants de Maldoror». https://www.salvador-dali.org/en/artwork/catalogue-raisonnesculpture/obra/7feab9bd42ece411947100155d647f0b/untitledwindow-display-for-the-exhibition-salvador-dali-42-eaux-forteset-30-dessins-pour-les-chants-de-maldoror-(Accessed $\underline{26.06 .2020)}$

Tiffany \& CO. Surreal Windows Display for Gene Moore:

Tiffany \& Co. is an American luxury jewelry and specialty retailer headquartered in New York City. Tiffany \& Co. was founded in 1837 by the jeweler Charles Lewis Tiffany and became famous in the early 20th century under the artistic direction of his son Louis Comfort Tiffany. It sells jewelry, sterling silver, crystal, stationery, fragrances, watches, personal accessories, and leather goods. Tiffany is known for its luxury goods, particularly its diamond and sterling silver jewelry. It markets itself as an arbiter of taste and style. Gene Moore, artistic director at Tiffany's for much of the second half of the twentieth century. Gene Moore born in Alabama, in 1910, Moore studied painting at the Chicago Academy of Fine Arts. He landed his first display job at I. Miller, where he worked from 1936-38, followed by Bergdorf Goodman in its Delman's shoe division, and, in 1945, he moved to Bonwit Teller as display director. His domain was for Tiffany, in the five Fifth Avenue windows, three feet tall, 22 inches deep, each with a width that Moore adjusted to best suit his chosen composition, which often was less than the four feet maximum space available. (Orr, 2017). Moore built his reputation on sparse displays whose severely edited presentation nonetheless made an incredible visual impact. Moore showed how just a few expertly arranged surreal objects could make for a much more compelling and attention-getting visual statement than the packed windows of many of his Fifth Avenue 
neighbors. It was this contrasting visual impression that made passersby stop in their tracks. When Moore started in 1955, Walter Hoving, chairman of Tiffany's, gave him free reign to be creative. With some of the most luxurious and beautiful objects that Fifth Avenue had to offer, Moore explained, "I never build anything around merchandise, I make merchandise work for me." He placed precious jewels in unlikely contexts in a surreal manner. A whole series in August of 1956 used a craggily dirt-laden cavern as a backdrop. As if discovering diamonds in the rough, the jewels were spot lit to glow against the rough and natural background. Moore explained that with his window schemes he called attention to the beauty in more than the luxurious Tiffany wares themselves, "I show people things they've looked at before but really haven't seen like dirt. Dirt can be beautiful." "Figure 7".https://www.cooperhewitt.org/2017/10/04/cooper-hewittshort-stories-watch-this-window/ - (Accessed 14.07.2020).

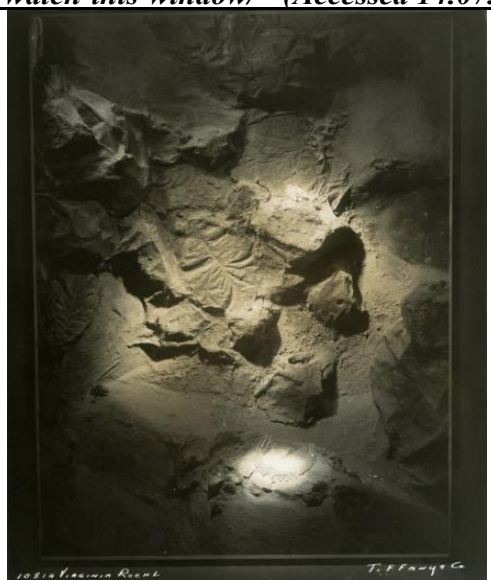

Figure 7: Window Display, August 30th, 1956. Photo by Virginia Roehl. Gene Moore, Tiffany \& Company

Photographs, 1955-1995, Archives Center, National Museum of American History, Smithsonian Institution. AC12800000074. https://www.cooperhewitt.org/2017/10/04/cooperhewitt-short-stories-watch-this-window/ - (Accessed 14.07.2020). The surrealism characteristics were obvious in windows display designs, Moore used unexpected treatments, such as the use of a backdrop of drab dirt for glamorous jewelry, to guarantee that passersby would stop to examine his windows carefully. Moore identified that there is a difference between looking and seeing. His windows were intellectual and engaged with consumers well beyond the commercial. Moore had a few visual tropes that he used again and again throughout his career: articulated wooden figures, eggs (broken or whole, which he considered to have the most perfect shape), birds, zippers, and keys. "Figure 8 ".

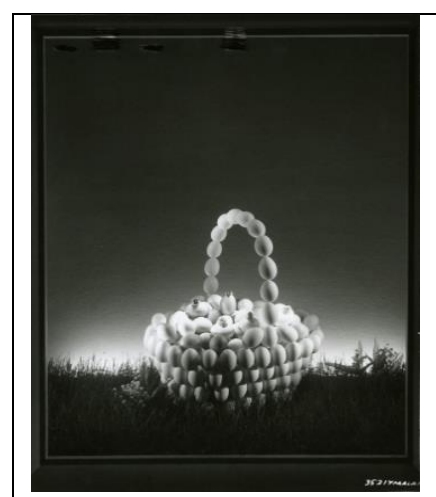

Window Display, April 1,

1965. Photo by Virginia Roehl. Gene Moore, Tiffany

\& Company Photographs, 1955-1995, Archives Center,

National Museum of

American History,

Smithsonian Institution AC1280-0000986.

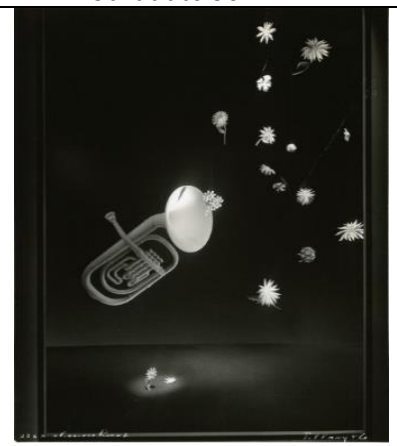

Window Display, April 22, 1957. Photo by Virginia Roehl. Gene Moore, Tiffany \& Company Photographs, 19551995, Archives Center, National Museum of American History, Smithsonian Institution. AC1280-0000139.

Figure 8: Windows Display Designs Collection, Gene Moore, Tiffany \& Company Photographs, 1955-1995, Archives Center, National Museum of American History, Smithsonian Institution. AC1280-0000074.

https://www.cooperhewitt.org/2017/10/04/cooper-hewitt-shortstories-watch-this-window/ - (Accessed 14.07.2020).

Moore's designs often included visual twists and tricks that demanded careful seeing: broken elements and objects turned backwards or at odd angles that could shock passersby, or jewelry and silver nearly entirely masked by an artistic background that rewarded the public with an element of visual discovery. Moore embraced the beguiling effects of surrealism. He theatrically staged situations that were impossible, and sometimes left viewers feeling unsettled with surprising schemes for the storefront of a luxury shop such as Tiffany's. Moore's designs often earned their visual impact from the succinctness of the concept conveyed: a necklace in the mouth of a bird or jewelry 
emanating from a euphonium in the form of musical notes. Gene Moore is the master window wizard, and his five Fifth Avenue windows were his street gallery museum. His creations became a New York must see destination. Gene has given a rich legacy of window design that included wit, brilliant merchandising savvy, and notoriously unconventional methods for getting people to stop and enjoy his visual merchandising creations. (Orr, 2017)

\section{Contemporary Window Display Design}

\section{- Hermès Surreal Windows Display:}

Hermès International S.A., or simply Hermès is a French high fashion luxury goods manufacturer established in 1837. The collaboration between the Dutch artist, Kiki Van Eijk and Hermès never ceases to amaze audiences, for the spring / summer season 2019 , she has been chosen again. "Surreal" is the story that on this occasion the designer has developed for Hermès windows displays in Spain and Portugal. Taking as a source of inspiration Paris and its most emblematic places, the artist has created a series of windows displays that show us the interior and exterior of a city bathed by surrealism, the fusion of reality with fiction lets us see a story in each showcase. A tour of the Église de la Madeleine, the Jardin du Luxembourg, the Pyramide de Louvre, the Arc de Triomphe or the interiors of a french house. All of them are the spaces chosen to present the new Hermès season. As in previous occasions Hermés designs, each item, each product, comes alive and joins the story created by the artist as a decorative element, takes its role and develops it. Each showcase is a different scene and has been carried out based on a special design with elements that represent a place in Paris. The surrealism, the art, the designs of Kiki Van Eijk demonstrate once again how the fusion with the world of fashion and its entry into the design of windows displays, in this case those of Hermès, has a special result. We can begin by describing the showcase dedicated to the Jardin du Luxembourg, a look in which the women article shown items are fused with Hermès fabrics, wood and metal. For the men windows displays Kiki Van Eijk has developed a vision of the Église de la Madeleine the Catholic church located in Paris, in which wallets, bags or hats fly carried by clouds of felt between the columns of this historic building. "Figure 9"

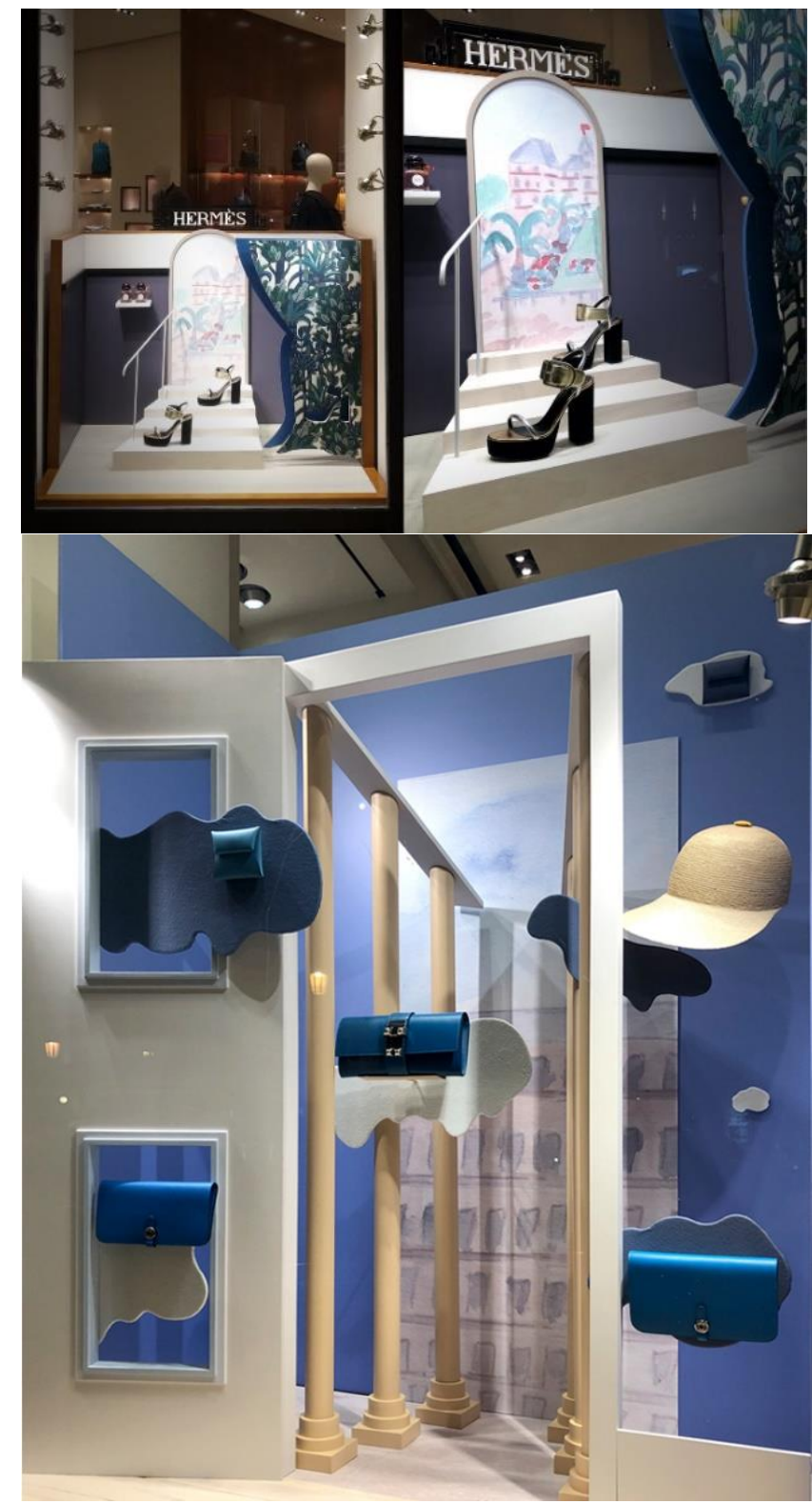

Figure 9: Hermès Surreal Windows Display Collection, "A vision of the Église de la Madeleine", by the Dutch designer Kiki Van Eijk

https://luxuryretail.co.uk/surreal-by-kiki-van-eijk-for-hermes/ (Accessed 12.07.2020)

Jewelry and silk are showed with the Arc de Triomphe in the background. Made in lacquered wood, the Arc is decorated with pieces of Hermès jewelry and silk designs that fly thanks to the methacrylate supports.

"Figure 10". 


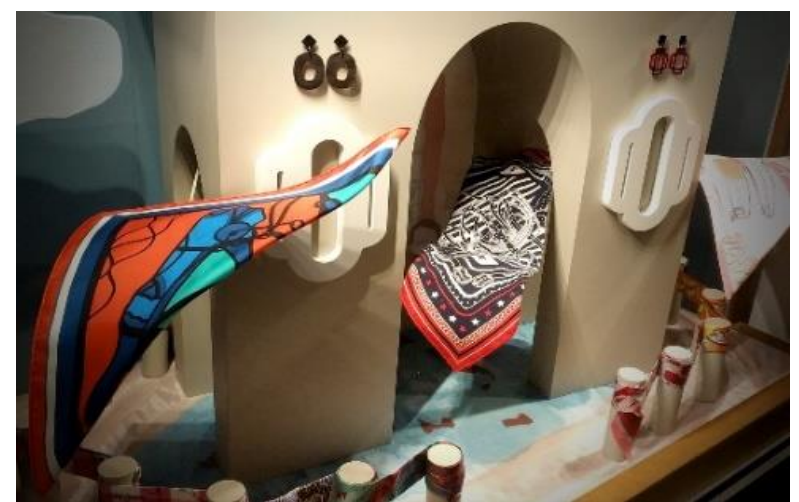

Figure 10: Hermès Surreal Windows Display Collection, "A vision of Arc de Triomphe", by the Dutch designer Kiki Van

Eijk https://luxuryretail.co.uk/surreal-by-kiki-van-eijk-forhermes/ - (Accessed 12.07.2020)

The Louvre and Mont St. Michel also have their representation. A pyramid made of methacrylate and metal and a staircase in lacquered wood are the supporting elements for shoes, silk ties and leather wallets. "Figure 11"

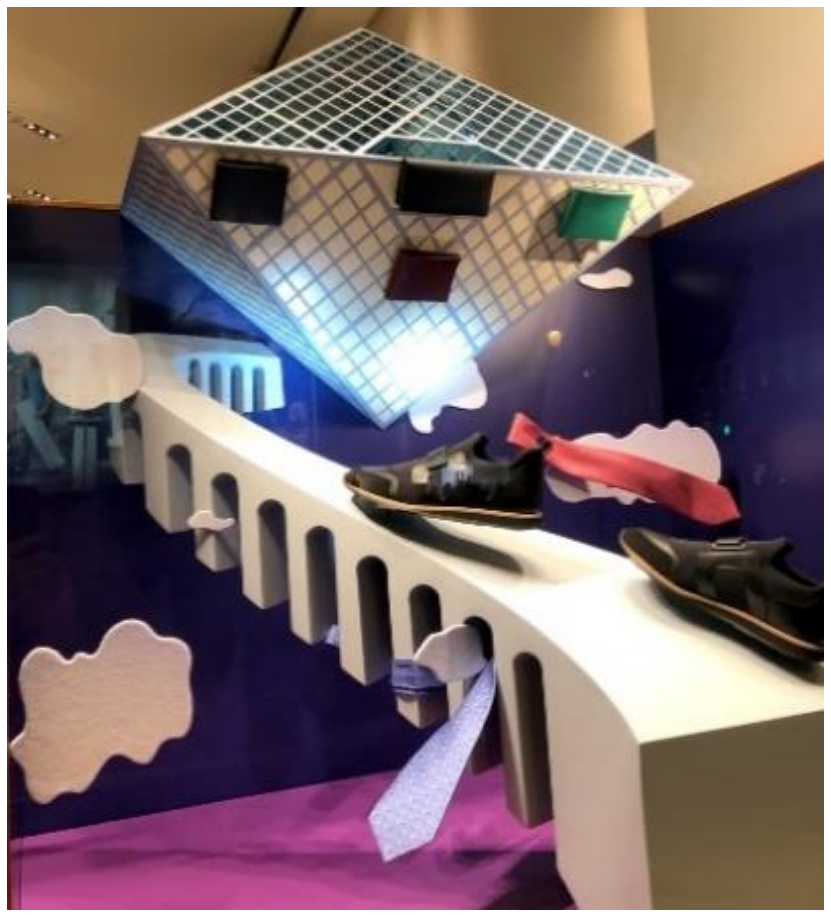

Figure 11: Hermès Surreal Windows Display Collection, "A vision of The Louvre and Mont St. Michel”, by the Dutch designer Kiki Van Eijk https://luxuryretail.co.uk/surreal-bykiki-van-eijk-for-hermes/ - (Accessed 12.07.2020)

\section{Selfridges Surreal Windows Display:}

Selfridges, also known as Selfridges \& Co., is a chain of high-end department stores in the United Kingdom that is operated by Canadian group
Selfridges Retail Limited, part of the Selfridges Group of department stores. It was founded by Harry Gordon Selfridge in 1908 . The flagship store on London's Oxford Street is the second largest shop in the UK (after Harrods) and opened 15 March 1909. Selfridges explored the influence of Surrealism on contemporary art and design with a series of collaborations in its Oxford Street store. Running in tandem with the Victoria and Albert museum's exhibition, Surreal Things: Surrealism and Design (29th March to 22nd July 2007), Selfridges' commissions demonstrated the powerful effect the movement continues to have on artists and designers today. At the height of the surrealist movement in the 1930's, artists such as Salvador Dali and Elsa Schiaparelli created window displays for forwardthinking shops. Selfridges celebrated this tradition by inviting current designers influenced by the Surrealist movement to create unique and thought-provoking schemes. Commissioned designers included John Galliano, Viktor \& Rolf, Maison Martin Margiela, and Moschino. Each of them was given free region to create a surrealist world within one window. The result is a must-see for all lovers of the art. Rather than the usual handbags, clothes and jewelry, the Oxford Street store's windows now contain such oddities as naked mannequins in cages, an upside-down tailor's dummy, chair and chandelier and a life-sized model of a horse with a lampshade on its head. "Figure 12"

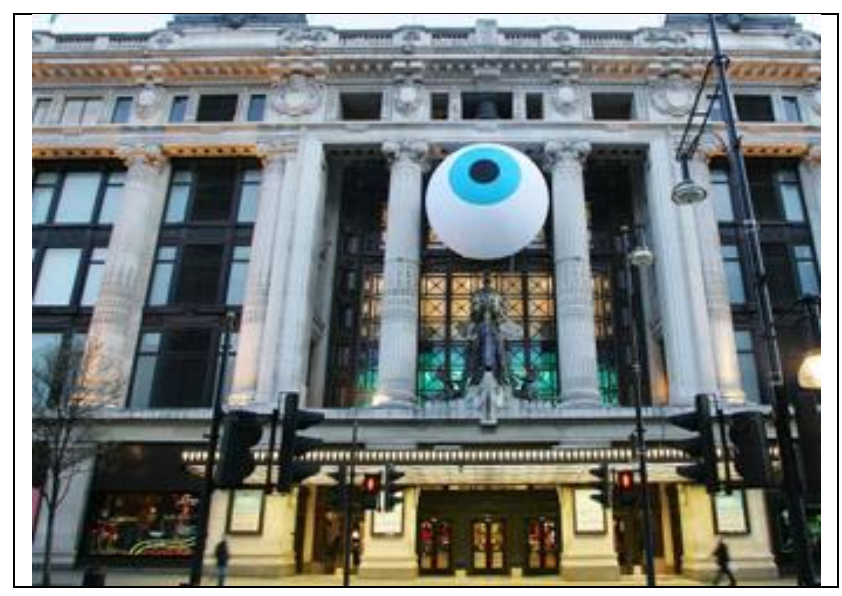




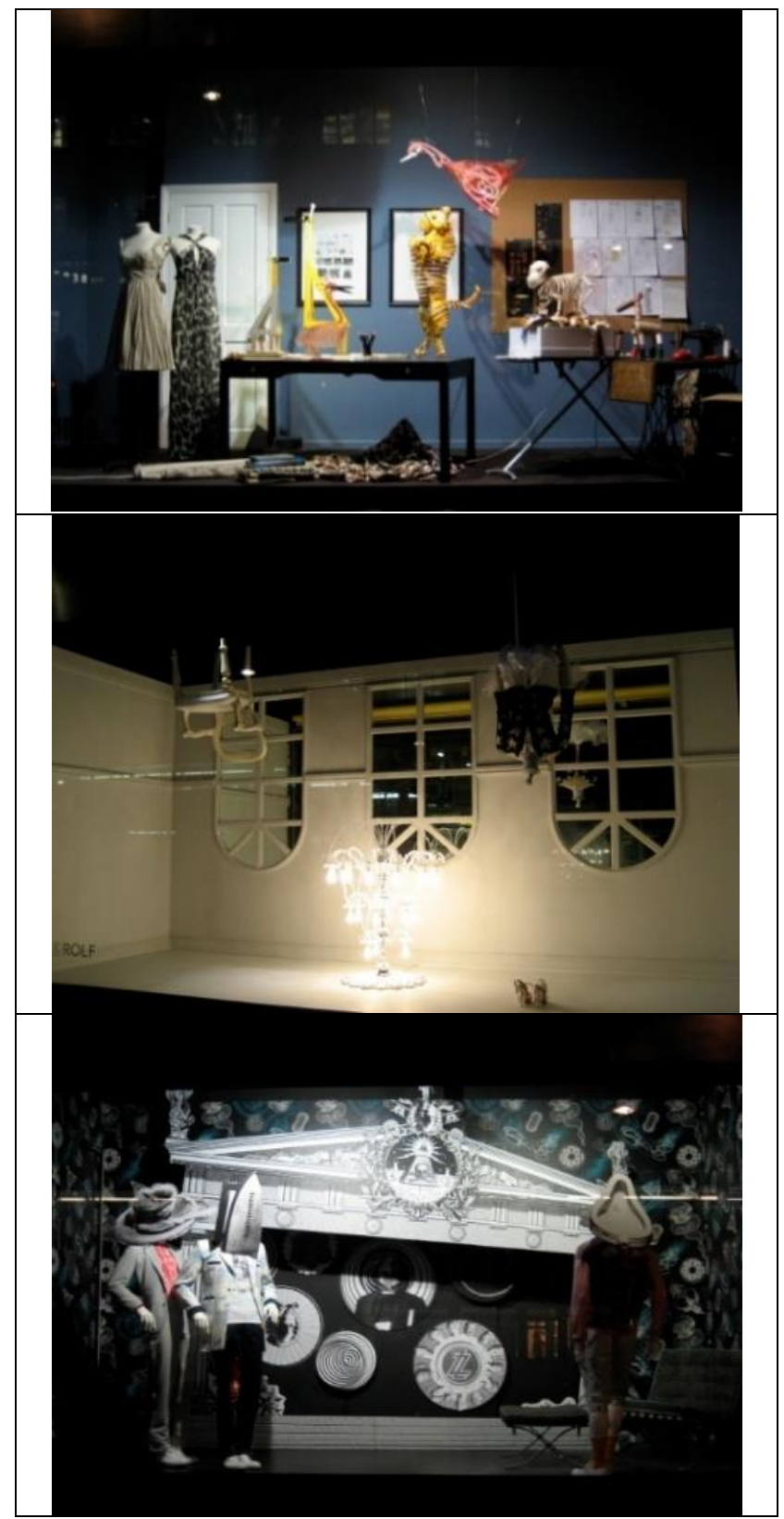

Figure 12: Selfridges Windows Display Collection "Surreal Things: Surrealism and Design”, 2007, by John Galliano, Viktor \& Rolf, Maison Martin Margiela, and Moschino https://brandonblog.wordpress.com/2007/03/31/surrealism-andselfriges/ - (Accessed 12.07.2020)

Also, as a part of the collection Surreal Things: Surrealism and Design, Selfridges requested the Swiss designer and artist Rolf Sachs to create 'Surrealist' windows for its London store, as well as selling 'Surreal' pieces of his, such as 'a bottled clock'. Of course, the shop window and the mannequin were favored tropes of Surrealism. Retailers were quick to return the compliment, already adopting Surrealism as a window display-style in the 1930s. The Swiss artist and designer Rolf Sachs (https://rolfsachs.com/about, Accessed 12.07.2020) design a surrealist concept for Selfridges, as a portmanteau of surrealism was presented; bringing together elements from across the surrealist oeuvre and a collection of his own studio pieces to create the window; using clock faces, neon lights, mirrored picture-frames and the spineless to create a thoughtprovoking and humorous experience. The design included creating a series of surreal items to sell in the store, such as 'bottled time;' a clock face mounted on a rod, gazed on by the miniature figurines; open-ended vase; a deconstructed, open-ended vase, with a watertight silicone bung; and 'a light plunge;' a humble utilitarian plunger, given a minimal, decorative function, with the addition of a wax candle. "Figure 13"

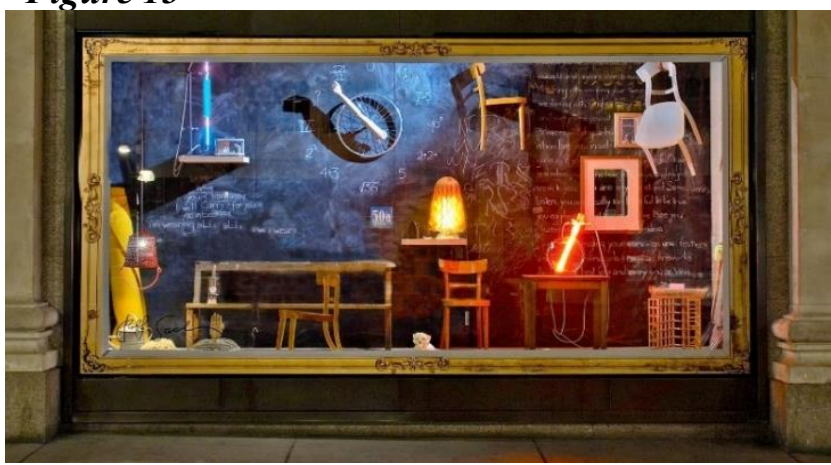

Figure13: Selfridges Windows Display Collection "Surreal Things: Surrealism and Design”, 2007, by Rolf Sachs https://rolfsachs.com/works/surreal-things-surrealism-anddesign - (Accessed 12.07.2020)

\section{Results}

1- The Surrealism approach is a creative design strategy of windows display design throughout the aesthetics, characteristics, and techniques.

2- Surrealism approach is the most important way is to present the merchandise in visually and imaginative ways that it engages the customer and compels them to buy.

3- The Surrealist Themed window display designs feature the elements of surprise, unexpected juxtapositions and non sequitur, which strongly catch the attraction of customers to the store.

4- Surrealism design approach achieves creativity and originality to ensure visibility for the brands and products in windows display designs.

5- The modernist windows display design would enhance decipherability and memory through 
counting on Surrealism approach as a design strategy and thereby influence consumer behavior.

6- The skill of the window display designers reside in the transformation of display into works of art or "street theatre" that have the power to captivate an ever more discerning set of pedestrians.

7- The good use of surrealism characteristics is worth remembering and sharing a must in our current social landscape.

8- The surrealism for the revelation of the unconscious realms shares the inner world of mentality with window display for the visual expression of sensation each other, to provide passersby with "retail theatre", or a shopping experience unlike anywhere else.

\section{Conclusion}

Surrealism is a cultural and art movement that originated in the 1920s influenced by the extensive research into the psyche that occurred during the first quarter of the 20th century. Surrealism was an art and literary movement that utilized fantasy, myth, and dream imagery when creating art. The Surrealist movement began in Europe in the 1920's as a reaction to the atrocities an

$\mathrm{d}$ of World War I and the cultural-political values of the time period. Surrealists explored the darker, subconscious side of human nature through art. Surrealism often takes the form of hyper-creativity and features the element of surprise using random objects and unpredictable juxtapositions. The most famous surrealist artist Salvador Dali tried to translate the subconscious mind into visual art. The impact the surrealist movement has had on modern commercial art like advertisements, movies, and windows display. It's almost so commonly used nowadays, and sometimes so subtly, that it's overlooked. Surrealism is a highly effective tactic when windows display is designed to entice us and make us think. This paper is a close-up study of the influences of Surrealism as an art movement on the design practices of window display. This paper studied and analyzed the creation of surrealistic windows display. It describes the effects of surrealism approach on windows display design. It shows and analyses the display designs of Salvador Dali for both "Bonwit Teller Store" and "Les Chants de Maldoror". The paper also analyses the window display designs for the three famous brands Tiffany \& $\mathrm{CO}$, Hermès, and Selfridges that use the Surrealism as a creative design theme for their display. The paper was conducted using the descriptive method to describe the Surrealism approach as a creative design strategy of windows display design throughout the study of the aesthetics, characteristics, and techniques of Surrealism in display design. This paper also uses the analytical method to analyze Salvador Dali windows display designs, also to analyze a chosen example of windows display for the famous brands "Tiffany \& CO, Hermès, and Selfridges" that use Surrealism in their windows display designs. Salvador Dali works contain fantastic imagery that affects the windows display design by means of unnatural, irrational juxtapositions and combinations. Surrealism approach in window display designs is the belief that unconventional visual imagery could be used to unlock hidden motivations, and tap into windows display consumer's desires, surreal display is designed to resonate in the viewer's mind, to shock, provoke or entice the audience, so that they retain the store brand information.

\section{References:}

1- Breton, A, 1969. Manifestoes of Surrealism. 1st ed. USA: The University of Michigan Press.

2- Lesley-Ann Daly, 2013, The Appropriation of Surrealism as an Aesthetic for Consumption, Institute of Art, Design and Technology, Dun Laoghaire.

3- Charlotte Klonk, 2005, "Patterns of Attention: From Shop Windows to Gallery Rooms in Early Twentieth-Century Berlin", Art History, Wiley online library, Vol. 28, No.4.

4- Frederick Kiesler, 1930, "Contemporary Art Applied to the Store and its Display”, New York, Brentano's, McGill University Library.

5- Keith Walden, 1989, "Speaking Modern: Language, Culture, and Hegemony in Grocery Window Displays 1887 1920", Canadian Historical Review, LXX, No. 3, p. 301;

6- Lester Gaba, 1952, "The Art of Window Display”, New York, Studio Publications in Association with Crowell.

7- Moore, Gene and Jay Hyams. 1990, "My Time at Tiffany's”. New York, St. Martin's Press,

8- Sandra Zalman, 2018, "A Way of Life": The Museum of Modern Art and the Marketplace for Surrealism, University of Houston, volume 14, 2018 | Dada and Surrealism: transatlantic aliens on American shores, 1914-1945 (8/26), Retrieved from: https://scalar.usc.edu/works/thespace-between-literature-and-culture-19141945/vol14_2018_zalman - (Accessed $\underline{26.12 .2019)}$ 
9- Anna Dahlgren, Sept. 2010, "The Art of Display", Journal of Art History, Institutet för folklivsforskning, Stockholm, Sweden, Publisher Routledge

10- Dana Louise Ostrander, 2013, Graduate College of the University of Illinois at Urbana-Champaign

11- Bide, B (2018) "More than window dressing: visual merchandising and austerity in London's West End", 1945-50. Business History, 60 (7). pp. 9831003. ISSN 0007-6791

12- YiTing Paung, 2017, "Surrealism: Art of Subconscious", Union College - Schenectady, NY. https:// digitalworks.union.edu/theses

13- Carmen Cabezas Fontanilla \& Ana Isabel Bastos Boubeta, (2010), Design techniques for window dressing. A practical guide to methods, materials and procedures, Ideaspropias Editorial, Vigo, 2010, ISBN: 978-84-9839-222-7

14- Emily Orr, 2017, Cooper Hewitt Short Stories: Watch This Window, Retrieved from: https:/www. cooperhewitt.org/2017/10/04/cooper-hewitt-shortstories-watch-this-window/ (Accessed 19.12.2021)

15- Juan Carlos Barrón, 2018, 7 Aesthetic Qualities Proving Visual Merchandising is Art, Retrieved from: https://visualretailing.com/blog/2018/04/visual-merchandising-is-art (Accessed 19.12.2021)

16- Eun-Kyung Lee, 2003, Fashion Display by Automatism Techniques of Surrealism Paintings, Korean Journal of Human Ecology.

17- Rob Hooks, 2018, Surrealism in graphic design. Retrieved from: https://99designs.ca/blog/design-history-movements/surreal-graphic-design/ Accessed 19.12.2021).

18- Seungyeun Heo \& Younhee Lee, 2013, Article: The characteristics expressed in visual merchandising of Maison Herm??s - Focused on the window displays. The Research Journal of the Costume Culture 21(1). DOI:10.7741/rjcc.2013.21.1.017

\section{Websites:}

1. Willard Martin, 2018, design trends report. Available at: https://webdesigntips.blog/web-design/photoshop-tips-tricks/design-trend-report-surrealism, Accessed 07.07.2020) https://creativemarket.com/blog/ design-trend-report-surrealism - (Accessed 08.07.2021)

2. https://1stwebdesigner.com/modern-surrealism/\#: :text $=$ The $\% 20$ Surrealism $\% 20$ art $\% 20$ movement $\% 20$ had,alive $\% 20$ and $\% 20$ growing $\% 20$ until $\% 20$ today. - (Accessed 08.07.2021)

3. https://www.britannica.com/art/Surrealism - (Accessed 08.07.2021)

4. Ghislaine Wood, 2007, https://www.vam.ac.uk/articles/sur- realism-and-design - (Accessed 08.07.2021)

5. https://rolfsachs.com/about - (Accessed 12.07.2020)

6. http://www.nineam.co.uk/index.php/projects/project/surrealism_season/ - (Accessed 10.07.2020)

7. https://brandonblog.wordpress.com/2007/03/31/surrealism-and-selfriges/ - (Accessed 12.07.2020)

8. https://expressdigest.com/salvador-dalis-lobster-telephonewill-leave-uk-unless-buyer-found/ - (Accessed 07.07.2020)

9. https://greg.org/archive/2019/03/26/destroyed-andy-warhol-fences.html - (Accessed 09.07.2020)

10. https://i-d.vice.com/en_uk/article/7xbvpd/how-andy-warhol-used-the-store-window-display-to-launch-a-career (Accessed 09.07.2020)

11. https://luxuryretail.co.uk/surreal-by-kiki-van-eijk-for-hermes/ - (Accessed 12.07.2020)

12. https://mannequinmall.com/blogs/posts/attracting-attention-with-surreal-window-display-design - (Accessed 26.06.2020)

13. https://rolfsachs.com/works/surreal-things-surrealism-and-design - (Accessed 12.07.2020)

14. https://www.artgallery.nsw.gov.au/blog/posts/artist-in-thewindow/ - (Accessed 09.07.2020)

15. https://www.cooperhewitt.org/2017/10/04/cooper-hewittshort-stories-watch-this-window/ - (Accessed 12.07.2020)

16. https://www.designweek.co.uk/issues/8-march-2007/rare-commodities/ - (Accessed 12.07.2020)

17. https://www.drivingfordeco.com/stewart-and-company/ (Accessed 07.07.2020)

18. https://www.ft.com/content/33b297a8-4cdd-11e5-b558$8 \mathrm{a} 9722977189$ - (Accessed 26.06.2020)

19. 19- https://www.independent.co.uk/arts-entertainment/ fashion-window-shopping-1526249.html - (Accessed 12.07.2020)

20. https://www.salvador-dali.org/en/artwork/catalogue-raisonne-paintings/obra/418/three-young-surrealist-womenholding-in-their-arms-the-skins-of-an-orchestra - (Accessed 07.07.2020)

21. https://www.salvador-dali.org/en/artwork/catalogue-raisonne-sculpture/obra/7feab9bd42ece411947100155d$647 \mathrm{f} 0 \mathrm{~b} /$ untitled-window-display-for-the-exhibition-salvador-dali-42-eaux-fortes-et-30-dessins-pour-les-chants-demaldoror - (Accessed 26.06.2020)

22. https://static 1 .squarespace.com/static/52ca9f04e$4 \mathrm{~b} 083$ e 90 ec $41 \mathrm{c} 17 / \mathrm{t} / 5 \mathrm{cf} 901 \mathrm{afb} 02 \mathrm{bea} 0001 \mathrm{e}$ 0b23e/1559822774415/Visual+Retailing + White $+\mathrm{Pa}-$ per+-+How+to+VM.pdf - (Accessed 19.12.2020)

23. https://thecityateyelevel.com/stories/art-in-display-windows-as-a-street-catalyst/ - (Accessed 19.12.2020)

24. https://www.ft.com/content/33b297a8-4cdd-11e5-b5588a9722977189 - (Accessed 19.12.2020)

25. https://www.theartstory.org/blog/category/public-art/\#post-707 - (Accessed 19.12.2020)

26. https://visualretailing.com/blog/2018/2/the-power-of-storytelling-in-visual-merchandising (Accessed 19.12.2020) 